DOI: http://doi.org/10.21698/simi.2018.fp28

\title{
IDENTIFYING AND DESCRIBING THE MAIN CLIMATIC AND STRESS FACTORS THAT ARE AFFECTING FOREST AND VITICULTURAL ECOSYSTEMS
}

Diana Elena Vizitiu ${ }^{1}$, Lucian Dinca ${ }^{2}$, Viorica Enache ${ }^{3}$, Alina Donici ${ }^{3}$, Lucretia Popa ${ }^{4}$, Danut Cociorva $^{5}$, Gabriel Murariu ${ }^{6}$

\begin{abstract}
${ }^{1}$ National Research and Development Institute for Biotechnology in Horticulture Stefanesti Arges, Stefanesti City, 37 Bucharest - Pitesti Avenue, Arges, 117715, office@incdbhstefanesti.ro, Romania

${ }^{2}$ National Research and Development Institute in Forestry”Marin Dracea”, 128 Eroilor Blvd., Voluntari, Ilfov, 13 Closca, Brasov 500035, icas@icas.ro, Romania

${ }^{3}$ Research and Development Station for Vine and Winemaking Bujoru, Tg. Bujor City, 65 Gral Eremia Grigorescu, Galati District, 805200, scdvvbujoru@gmail,com, Romania

${ }^{4}$ National Institute of Research-Development for Machines and Installations Designed to Agriculture and Food Industry, 6 Ion Ionescu de la Brad Blvd., district 1, Bucharest, 71592, icsit@inma.ro, Romania

${ }^{5}$ National Institute for Research and Development in Environmental Protection, 294 Splaiul Independentei, district 6, 060031, Bucharest, incdpm@incdpm.ro, Romania

${ }^{6}$ Faculty of Sciences and Environment, Department of Physics, Chemistry and Environment, „Dunarea de Jos” University of Galati, 47 Domneasca, 800080, Galati, decanat.stiinte@ugal.ro, Romania
\end{abstract}

\begin{abstract}
Climatic changes represent one of the main preoccupations of our century - a complex domain in which the knowledge must be continuously improved and understood in order to efficiently approach the challenges from this field. Climatic changes determined by a multitude of natural and anthropic causes (for example: atmospheric pollution, soil erosion, afforestation and field degradation) lead to an intensification of negative processes. Amongst these, we mention the intensification of climatic changes, the increase of afforestation surfaces, reducing biodiversity, degrading soils and the apparition of desertification processes, as well as population migration, depletion of resources and the occurrence of social conflicts. On their own end, climatic changes induce an aggravation of abiotic and biotic threats posed on forests such as: fires, droughts, storms, atmospheric pollution, forest fragmentation as consequence of transport and infrastructure constructions etc. During the last couple of years, Romanian forests and fields destined for afforestation were negatively affected by: torrential phenomenon, landslides and river breaches, surface erosions, surface rocks, depth erosion, floods or freezing rain. Climate represents one of the main natural factors both in ensuring viticultural growth and development conditions, as well as in establishing and scaling management works for peaks and irrigations. The main climatic and stress factors that have affected the viticultural ecosystem in the last period of time are:
\end{abstract}




\section{INTERNATIONAL SYMPOSIUM "THE ENVIRONMENT AND THE INDUSTRY", SIMI 2018, PROCEEDINGS BOOK}

temperature, precipitations, atmospheric humidity, average global, active and useful temperatures, night humidity index and the Huglin index.

Keywords: grapevine, precipitation, soil, temperature, trees

\section{Introduction}

Climatic changes represent one of the main challenges and the biggest social dilemma that humanity has to face. These changes can have significant effects on forests (changing the distribution of tree species by translating phytoclimatic levels at other latitudes and altitudes) and agriculture. The viticultural production is especially influenced because these cultures are extremely sensible towards the environment, while seasonal variations of grape productions are much larger than other common cultures, such as cereals. On a long term, climatic changes can cause major geographic changes in traditional viticultural production areas, threatening traditional wine areas such as France and Italy.

Climatic conditions (solar radiation, heat accumulation, extreme precipitations, frost intensity and duration, diurnal temperatures, humidity etc.) have a strong impact on grapevine cultures, impacting the grapevines growth and development, the apparition of certain diseases or the wine's chemical and organoleptic characteristics. In low afforested and hill areas, a considerable decrease of forest productivity is estimated after the year 2040 due to the increase of temperatures and the decrease of precipitation volume.

\section{Materials and Methods}

Climatic changes are determined both by internal factors (changes that appear inside the climatic system or caused by the interactions between its components), as well as external natural factors (solar energy variation, volcanic eruptions, Earth's orbital parameters variation) or external anthropogenic factors resulted from human activities (changing the atmospheric composition as a result of increasing the concentration of greenhouse gases).

The present study has analysed the changing tendencies of temperature and atmospheric precipitations in Romania. As such, the following aspects were studied: the impact of climatic changes over forest ecosystems and their regulation options based on the areas geographic location, the main factors that affect forests, the damage percentage of trees on biogeographical regions from Romania. Furthermore, pathogen agents that bring damages in grapevine plantations from Stefanesti viticultural centre and Dealul Bujorului vineyards were also identified, while their climate was also analysed in the period 1980-2016.

\section{Results and Discussion}

Forest and viticultural ecosystems are facing nowadays more harmful ambiental tendencies, among which the most important ones are: obvious climatic changes represented especially by the growth of temperatures with profound ecological 


\section{INTERNATIONAL SYMPOSIUM "THE ENVIRONMENT AND THE INDUSTRY", SIMI 2018, PROCEEDINGS BOOK}

effects (drought, heat waves etc.); harmful agents bioinvasion (diseases, harmful agents, weeds) adapted to the new habitat conditions; production decreases.

Climatic changes produced by different causes and processes such as atmospheric pollution, soil erosion, clearance and field degradation cause massive forest productivity loses with major implications on the economy. Statistical data show that the forest surface from Romania affected by abiotic and biotic factors has evolved during the last 50 years from $4 \%$ (in 1954) to $28 \%$ (in 1998).

The last years have shown an increase in the frequency of extreme temperatures (heats) that are amplifying the stress caused by drought. Some species are more sensible towards this climatic parameter. Drought has affected annually an average of 56.809 ha and especially young cultures from Dobrogea, the south and east of Romania, with maximum values between 2002-2003 and 2007. The drought from these periods has also favoured the mass multiplication of some harmful insects (looper moths, bark insects).

Statistical data show that our country's forest surface affected by abiotic and biotic factors has evolved during the last 50 years as follows (Nitescu et al 1992, Simionescu et al 2001, Simionescu et al 2012):

- 1954 - 4\% (from which approximately 99\% are harmful biotic factors);

- 1965 - 12,5 \% (from which approximately 75\% are harmful biotic factors);

- 1975 - 14,7\% (from which 61\% are biotic factors and 39\% are abiotic factors);

- 1985 - 14\% (from which approximately 82\% are biotic factors and 18\% are abiotic);

- 1998 - 28\% (from which approximately 79\% are biotic factors and 21\% are abiotic).

Forest ecosystems from the plain area were strongly affected by drought, based on some structural changes, anthropogenic in their origin. After the droughts from 1945-1947 and 1955-1961, the tree drying process has amplified, being identified on approximately 40000 ha. After a stagnation period, drought intensifies after 1971, affecting larger and larger surfaces both for pedunculate oak as well as for greyish oak, pubescent oak and holm (Chira \& Chira 1998).

Mountain ecosystems where predominantly affected by strong storms. During the last years, the number of surfaces with fallen or ruptured trees has increased by ten and even hundred thousand hectares (Nitescu et al 1992, Simionescu et al 2001). During 1960-1961, wind has caused the fall of $3.534 .000 \mathrm{~m}^{3}$ Norway spruces, $1.214 .000 \mathrm{~m}^{3}$ common beech and $305.000 \mathrm{~m}^{3}$ oaks. These calamities were located both in the Oriental Carpathians as well as in the West Carpathians.

\section{Freezing rain}

As a consequence of a rare encountered meteorological phenomenon, namely freezing rain (Figure 1), associated with strong wind towards the end of the 2015 vegetation season (October) while trees were not yet foliated, crown and stem raptures were registered as well as falls/uproots in common beech and mixture common beech stands. This phenomenon was registered at over $550 \mathrm{~m}$ altitude, especially in Magura Odobesti area, on superior slopes, with an estimated 1000 ha surfaces affected (Constandache et al 2018). Furthermore, a correlation between 


\section{INTERNATIONAL SYMPOSIUM "THE ENVIRONMENT AND THE INDUSTRY", SIMI 2018, PROCEEDINGS BOOK}

altitude and harmful intensity was observed, namely that the harmful intensity decreases as the altitude also decreases.

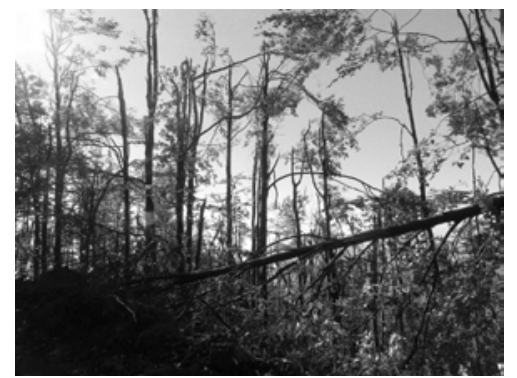

Figure 1. Stand affected by freezing rain Vidra forest district, Vrancea County

Drought has affected on average 56.809 ha $(19,1 \%$ of the surface affected by abiotic factors). This phenomenon has mainly affected young plantations especially from Dobrogea, South and East Romania, with maximum values in the years 20022003 and 2007 (Simionescu et al 2012). The last years have been characterized by an increase of extreme temperatures (scorches) which amplify the stress caused by drought as some species are more sensitive towards this climatic parameter. On the general drought background, unfavourable phenomenon for biocenosis can also appear such as the drying of forests and forest fires.

The drying of stands is the result of a complex abiotic and biotic factors. However, statistical data emphasize a significant general decrease of drying stands. In comparison with last 15 years (1986-2000), when this phenomenon has affected over 234.400 hectares, in the period 2001-2010 this number is significantly reduced to 45.400 hectares. The most affected areas affected in the period 2001-2010 were oak forests (67\%) and resinous forests (14\%). Annual oak dryings on a surface of over 30.000 hectares represents a low percentage in comparison with the previous period, both as surface as well as intensity (Chira \& Chira 1998, Simionescu et al 2001, 2012, Danescu et al 2015, Constandache et al 2016, Simonca et al 2017). This area is also characterized by the presence of natural and artificial shrubby associations composed of whitesea buckthorn (Constandache et al 2016), red sea buckthorn, small locust etc. The phenomenon causes, amongst other, decreases of tree growths (Silvestru-Grigore et al 2018). For resinous species, this phenomenon still affects fir species (75\%), in comparison with 13\% for Norway spruce or $12 \%$ for pine (Barbu 2017).

Forest fires were especially manifest in excessive drought periods, predominantly affecting young cultures. The largest surfaces affected by forest fires were registered in Caras Severin County (23\%). Most of them happened in 2007 and 2013 in more dry sites, usually as a consequence of cleaning pastures by fire (Adam 2007). 


\section{INTERNATIONAL SYMPOSIUM "THE ENVIRONMENT AND THE INDUSTRY", SIMI 2018, PROCEEDINGS BOOK}

Damages caused by forest fires are usually not significant, mainly due to forest compositions comprised of broad-leaved species. On average, approximately 88 fires are caused annually, while the affected forest area is of 276 hectares. Compared with the total country's forest fund area, the annually fired surface represents $0.15 \%$.

\section{Torrential phenomenon}

In some Romanian hill and mountain areas, torrential phenomenon are strongly connected with uncontrolled human interventions. Besides the anthropic factor, an important role is also played by climatic factors as a result of climatic changes caused by global heating (Clinciu et al 2012). The most part of our country's forests are situated in areas with hill and mountain relief, high slopes and lithological sedimentary substratum, all contributing to the fields' vulnerability towards erosion, landslides or clogging (Dinca et al 2014, Sparchez et al 2013, Tarziu et al 2004).

Floods have caused damages on average surfaces of 11892 ha/year (four times higher than the average of 2800 ha/year recorded in the previous timeframe), from which $58 \%$ had a strong intensity. This phenomenon was dramatic in years with rich precipitations, for example 2005-2006 and 2010 (Danescu et al 2011, Simionescu et al 2012).

Landslides and bank ruptures are strictly local phenomenon (but which have increased 10 times in the last decade). This phenomenon has affected the banks of rivers with high debit that come from the mountain area. These fields represent segments from the most strongly altered environment: they favour and amplify ecological derangements, are the main focal point of alluvial alimentation during floods and are strongly affecting the biological and habitat diversities.

The proliferation of the main pathogen and harmful agents from vinicultural plantations is an important ecological phenomenon that is influenced by the zonal ecological factors and ecological plasticity. The main pathogen and harmful agents of grapes from the analysed vineyards are: Plasmopara viticola, Uncinula necator, Botrytis cinerea, Lobesia botrana, Tetranychus urticae, Calepitrimerus vitis and Eriophyes vitis. The main climatic factors that are affecting the viticultural ecosystems are: temperature, precipitations, atmospheric humidity, the sum of global, active and useful temperatures, the cool night index, and the Huglin index.

Romanian grapevine plantations located in Muntenia (Stefanesti viticultural centre) and Moldova (Dealul Bujorului vineyards) are more and more affected by climatic changes manifested in the last decades. The main factors that have influenced the studied vineyard plantations were: high temperatures, precipitations, hailstone, storms and rime.

Changing environment conditions have determined shifts in metabolism, growth and development processes, with negative influences over the plants quality and vitality (Figure 2A). Hailstone, through its mechanical (hitting) effect, has caused significant damages to grapevine plantations. In many cases the grape production was even irremediably compromised (Figure 2B). 


\section{INTERNATIONAL SYMPOSIUM "THE ENVIRONMENT AND THE INDUSTRY", SIMI 2018, PROCEEDINGS BOOK}

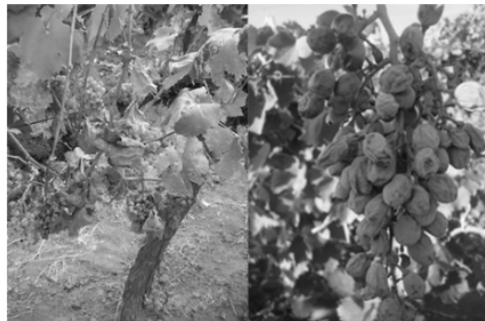

A

B

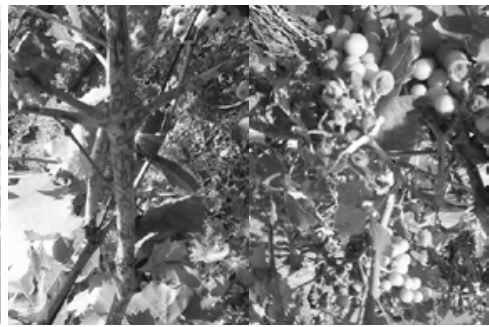

Figure 2. The effect of high temperatures and excessive drought (A) sand the effect of hailstone over sprouting and grapes (B)

Air temperature is a decisive factor in the development of grapevine plantations and in triggering the grapes phenophases. The most important inferior biological threshold is the $10^{\circ} \mathrm{C}$ temperature level that demarcates the length of the air's bioactive period (180-220 days in the temperate continental climate).

The evolution of temperatures in the two studied viticultural areas (Figures 3A and B) has not recorded significant differences: the multiannual temperature was of $10.9^{\circ} \mathrm{C}$ in Stefanesti and $11.4^{\circ} \mathrm{C}$ in Bujoru, the multiannual minimal temperature was of $6.4^{\circ} \mathrm{C}$ in Stefanesti and 5.8 in Bujoru, while the multiannual maximum temperature was of $16.2^{\circ} \mathrm{C}$ in Stefanesti and $16^{\circ} \mathrm{C}$ in Bujoru.

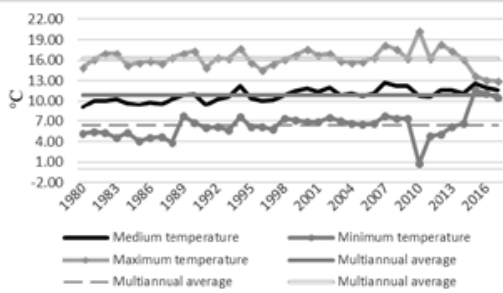

A

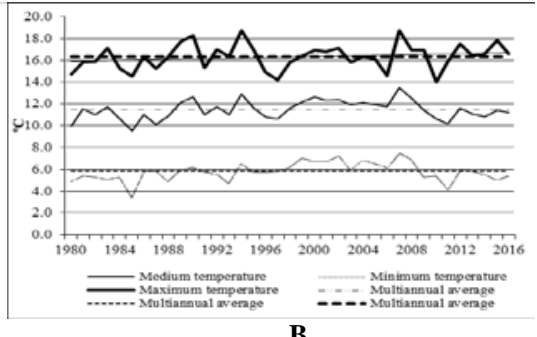

B

Figure 3. Temperature evolution in Stefanesti vinicultural centre (A) and Dealul Bujorului vineyards (B)

Grapevine culture is possible at an annual precipitation regime ranging between 400-700 mm, from which $250 \mathrm{~mm}$ during the vegetation period, uniformly distributed under the shape of useful rains $(>10 \mathrm{~mm})$. Average $691 \mathrm{~mm}$ were registered in Stefanesti viticultural areas, but the last 37 years have encountered an uneven distribution for them (Figure 4A). The precipitation's evolution in Dealu Bujorului vineyard (Figure 4B) marks a cyclical tendency of approximately 7-8 years, in which the rain interval alternates with the drought one. During the last period of time, a tendency for increased annual precipitations was observed with an 


\section{INTERNATIONAL SYMPOSIUM "THE ENVIRONMENT AND THE INDUSTRY", SIMI 2018, PROCEEDINGS BOOK}

uneven distribution of them over the entire year, with drought periods framed by short periods with abundant rains and usually with a torrential character.

The grapevine's requirements for the relative air humidity depend on the vegetation phenophase and range between 50-80\%. In both viticultural areas, the atmospheric humidity from the last 37 years has corresponded with the grapevine requirements (Figure 4A and B).

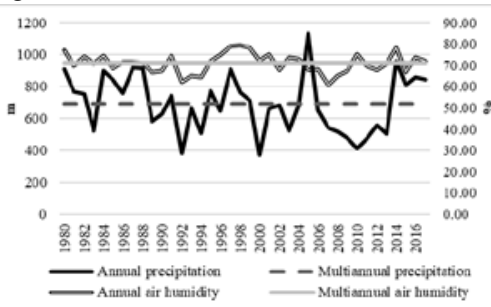

A

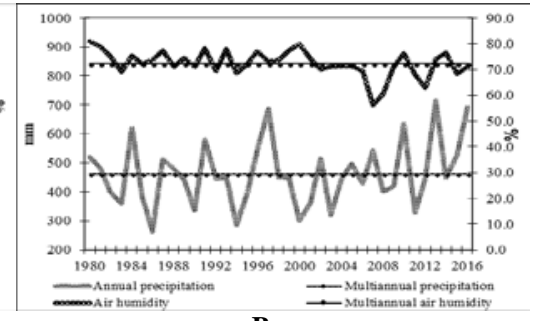

B

Figure 4. The evolution of precipitation and atmospheric humidity in Stefanesti vinicultural centre and in Dealul Bujorului vineyards

In Stefanesti viticultural area, the sum of global, active and useful temperatures was similar with multiannual averages. In comparison, Bujoru vineyard area records an increase of these value up to the year 2008, followed by a slight decrease until 2014 and then an increase until 2016 (Figure 5).
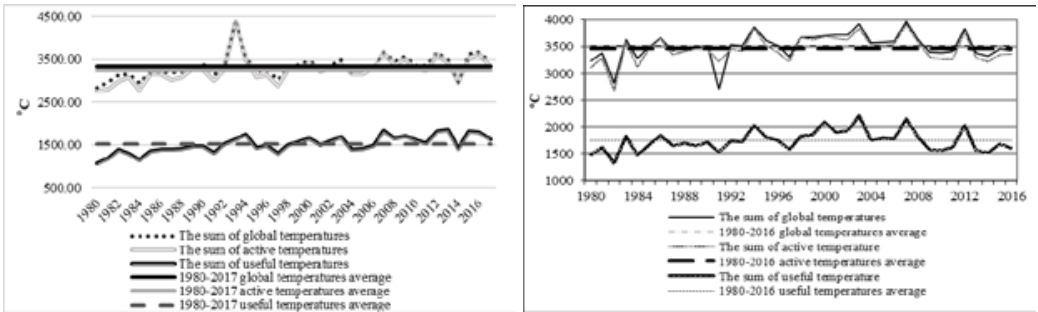

Figure 5. The evolution of multiannual sum of global, active and useful temperatures in Stefanesti vinicultural centre and in Dealul Bujorului vineyards

Huglin index (Figure 6) has values gathered between 1885 and 2667. During the last 37 years, only six years have a smaller than 2100 Huglin index, while all the other years have higher values. This aspect situates the territory as warm with cultivation possibilities for even late varieties situated in the $2100<\mathrm{HI} \leq 2400$ classification. 


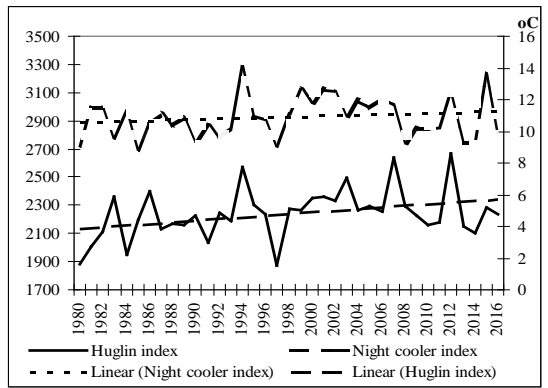

Figure 6. Huglin index and the night chill index in the period 1980-2016 in Dealul Bujorului vineyards

\section{Conclusions}

During the last couple of years, Romanian forests and fields destined for afforestation were negatively affected by: torrential phenomenon, landslides and river breaches, surface erosions, surface rocks, depth erosion, floods or freezing rain.

Drought and hailstone have negatively influenced the quality and vitality of grapevine plants, causing significant damages in grapevine plantations. Air temperature is a decisive factor in the development of grapevine plants, including triggering the grapevine's phenophase. The most important inferior biological threshold is the $10^{\circ} \mathrm{C}$ temperature level that demarcates the length of the air's bioactive period.

The culture of grapevines is possible in Stefanesti viticultural centre and in Dealul Bujorului vineyards even though the recorded precipitations were uneven. In Stefanesti viticultural area, the sum of global, active and useful temperatures was similar with the multiannual averages recoded in Bujoru vinicultural area.

\section{Acknowledgements}

This research was supported through the project 3PS „Investigations in support of evaluating and attenuating the influence of climatic changes and other stress factors over the health of forest ecosystems and vinicultural cultures". This project is funded by the Ministry of Research and Innovation.

\section{References}

Adam, I 2007, 'Method of assessing the fire risk in Romanian forests', Analele ICAS, vol. 50, pp. 261-271. In Romanian.

Barbu, I 2017, 'Modelling the distribution of sick fir trees based on the results obtained from the first monitoring network installed in 1986 in Bucovina', Revista de Silvicultura si Cinegetica, vol. 40, pp. 25-34. In Romanian. 


\section{INTERNATIONAL SYMPOSIUM "THE ENVIRONMENT AND THE INDUSTRY", SIMI 2018, PROCEEDINGS BOOK}

Chira, F \& Chira, D 1998, Forest decline in Romania. In: Cech T.L., Tomiczek C., Hartman G. (eds): Disease - Environment Interactions in Forest Decline, Proceedings of IUFRO Workshop “Complex diseases”, Vienna, pp.29-34.

Clinciu, I, Nita, MD \& Davidescu, S 2012, 'The state of torrential hydrographic watershed management and its role in the ecological reconstruction of the country', Forest Magazine, vol.127, no. 6, pp. 42-52.

Costandache, C, Peticila, A, Dinca, L \& Vasile, D 2016, 'The usage of Sea Buckthorn (Hippophae rhamnoides L.) for improving Romania's degraded lands', AgroLife Scientific Journal, vol. 5, no. 2, pp. 50-58.

Costandache, C, Dinca, L, Nistor, S \& Crisan, V 2016, 'Cauzele degradarii terenurilor in Vrancea. Masuri silvice de ameliorare a terenurilor degradate', Factori si Procese Pedogenetice din Zona Temperata, vol. 1, no. 15, pp. 5768.

Constandache, C, Dinca, L, Popovici, L, Braga, C \& Blaga, T 2018, 'The effect of climatic changes over some Romanian forest ecosystems', $18^{\text {th }}$ International Multidisciplinary Scientific Geoconference SGEM 2018. Conference proceedings, Soils, Forest Ecosystems, Marine and Ocean Ecosystems, vol. 18, no. 3.2, pag. 941-948.

Danescu, F, Mihaila, E, Costachescu, C \& Dragan D, 2011, Management measures of forest areas in the plainous region at risk of flooding and prolonged water stagnation, Ed. Silvica, Bucuresti

Danescu, F, Ungurean, C, Chira, F, Horga, D \& Jung, T 2015, 'Uscarea anormala a stejarului din O.S. Livada', Revista de Silvicultura si Cinegetica, vol. 37, pp. 66-79.In Romanian.

Dinca, L, Sparchez, G \& Dinca, M 2014, 'Romanian’s forest soil GIS map and database and their ecological implications', Carpathian Journal of Earth and Environmental Sciences, vol. 9, no. 2, pp. 133-142.

Nitescu, C, Simionescu, A, Vladescu, D \& Vladuleasa, A 1992, Phytosanitary status of forests in Romania during 1976-1985, Inter-Media Bucharest Publishing House. In Romanian.

Silvestru-Grigore, CV, Dinulica, F, Sparchez, G, Halalisan, AF, Dinca, L, Enescu, R \& Crisan, V 2018, 'The Radial Growth Behaviour of Pines (Pinus sylvestris L. and Pinus nigra Arn.) on Romanian Degraded Lands', Forests, vol. 9, no. 4, pp. 213.

Simionescu, A, Lupu, D, Badea, O, Mihalciuc, V, Vladuleasa, A \& Fulicea, T 2001, The state of forest health in Romania in the period 1986-2000, Musatinii Publishing House, Bucharest. In Romanian.

Simionescu, A, Chira, D, Mihalciuc, V, Ciornei, C \& Tulbure, C 2012, The state of forest health in Romania in the period 2001-2010, Musatinii Publishing House, Bucharest. In Romanian.

Simonca, V, Oroian, I, Chira, D \& Taut, I 2017, 'Methods for the Quantification of Decline Phenomenon and Determination of the Vulnerability Degree for the Oak Stands in Northwestern Transylvania', Notulae Botanicae Horti Agrobotanici Cluj-Napoca, vol. 45, no. 2, pp. 623-631. 
Sparchez, G, Tarziu, D \& Dinca, L 2013, Pedology with elements of Geology and Geomorphology, Transylvania University Publishing House, Brasov, pp.348. In Romanian.

Tarziu, D, Sparchez, G \& Dinca, L 2004, Pedology with elements of Geology, Silvodel Publishing House, pp. 343. In Romanian. 